\title{
A community perspective of spirit and healing in Africa
}

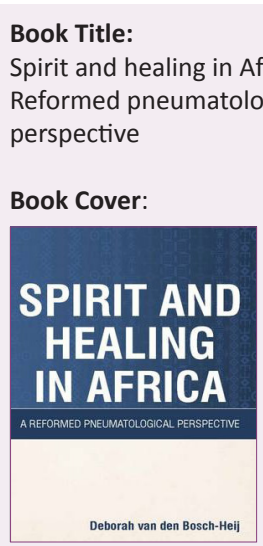

Author:

Deborah van den Bosch-Heij

ISSN:

978-1-4316-0712-9

Publisher:

SUN Media, Bloemfontein,

2012, R325.00*

*Book price at time of review

-

Review Title:

A community perspective of spirit and healing in Africa

Reviewer:

Raymond Potgieter ${ }^{1}$

\section{Affiliation:}

${ }^{1}$ Faculty of Theology,

North-West University,

Potchefstroom Campus,

South Africa

Email:

ray@csmdist.com

Postal Address:

PO Box 19491, Noordbrug

2522, South Africa

How to cite this book review:

Potgieter, R., 2014, 'A

community perspective of

spirit and healing in Africa', In

die Skriflig 48(1), Art. \#1809,

2 pages. http://dx.doi.

org/10.4102/ids.v48i1.1809

Read online:

口itas Scan this QR code with your smart phone or mobile device to read online.
The connection between spirit and healing is a subject featuring on any serious agenda dealing with spirituality, particularly in Africa. Amidst the offers to meet the need for spiritual and physical healing, a simple web search reveals topics such as ecstatic spirits and healing, spiritual herbalism, ancestral spirits and healing, healing and spiritual healing - not to mention the spells on offer as remedy for money matters, love, protection and more. This readable publication is an adaptation of Van den Bosch-Heij's useful doctoral thesis in systematic theology, which is from a generic Reformed perspective, and it will prove to be equally useful as a Christian sociological study of spirit and healing in community.

Part I (pp. 1-140) is a social discourse covering all levels of society - ranging from personal to communal expectations of medical and traditional practices. In particular it covers the sociological component, defining the complexity of concepts such as healing and/or health, which is contextually relevant in chapter 4, titled 'Discourse on HIV / Aids in Africa' (pp. 79-108). Van den Bosch-Heij shows that 'health' is a multilayered concept (p. 287; with examples of the differences between illness and healing on p. 138). Because the Western health model is basically divorced from theological foundations (pp. 55-56) and primarily focuses on the physical, it often gives the impression of superiority and dominance (p. 77) and is prone to misunderstand health and healing in Africa. This, in fact, breaks down essential information about health in the African context, where health issues are seen to include both the spiritual and physical as these pertain to individuals, family, community and society at large, thus linking religion and health (p. 70). This holistic approach is, however, virtually unknown in practice to persons holding to Reformed theology. They are traditionally dependent for their theological understandings as formulated in the West - developed in contexts vastly different to that in Africa. Consequently, Reformed theological churches have by and large avoided the claims of healing related to spectacular, immediate healing of the sick and demon-possessed. Van den Bosch-Heij has to fit into her Reformed background. She shows, for instance, how concepts such as 'life force/vital force' (p. 31f.) may relate directly to the Spirit who is 'the ultimate life-giving force of God' (p. 139) and thereby creates an environment for theological discussion. It is within this conceptual environment that the African healer functions, covering all levels of reality (spiritual and physical), and is the experience of a family in its communal and societal relational dynamics (p. 44f.). Van den BoschHeij tries to associate wholeness with religion, healing and power (p. 131) because her thesis explores the societal impact of the Spirit that relationally brings about transformation, well-being and more. Missing from this part of the book is an address of the more personal health needs of individuals. It seems as if Van den Bosch-Heij is aware of this. She tries to bridge this gap by introducing a fictitious character, Grace Banda (p. xiii). This character, in the reviewer's opinion, may just as well have been omitted, since it only shows a more personal management of health without addressing the desperation accompanying the need for actual physical and/or spiritual healing - or any other societal healing for that matter. Though this personal aspect is lacking in this study, it must be borne in mind that the thesis pertains to an extended audience and not simply to an individual's need for health and healing.

In Part II (pp. 141-289), Van den Bosch-Heij explores biblical pneumatology from a generic Reformed perspective, supposedly reflecting a Reformed theological discussion. She tries to maintain a trichotomous distinction between the Christological, Trinitarian and pneumatological (p. xix). To facilitate this discussion and test catechetical confines of Reformed theology, a structured matrix (model) for pneumatological discussion is established (p. 147ff.). One has to bear in mind that the author is offering options without claiming full exploration or a final word on the matter of her theological interpretation (p. 203). After visiting Calvin, Kuyper, Barth and Van Ruler (pp. 151-174), the author broadens her discussion through Moltmann's 'new way of thinking' (p. 174). This is augmented by Welker's inclusion of God's force field at work everywhere and Veenhof's extrapolation of Herman Bavinck's idea of the Holy Spirit restoring the good creation of God. In this process, the Spirit is mediating relationships between God and man, evident through experiential testimonies (pp. 181-189). From the aforementioned theological selections, Van den Bosch-Heij finds her links between God and the social concepts of relational, societal inclusion, relationality and transformation. 
She can now centre these sociological concepts present in the community within the context of religion, in particular among Reformed believers, and define, in her opinion, their Reformed content theologically for communal use - and possibly comfort. At once, however, she critically points out the poverty of the subject content by its explicit absence from the Heidelberg Catechism, though it is implicit from its salvific context - an obvious assertion.

Added to this is the further chink in the Reformed armour: the lack of power as an experiential component in healing and spiritual dimensions (pp. 198-200). Van den Bosch-Heij is of the opinion that 'one could say that Reformed theology works with an underdeveloped notion of divine power' ( $p$. 267). She tries to manage this by focusing on the dialectic and/ or paradox of, for instance, weakness and strength. As would be expected, she also struggles to maintain correspondence between God's immanence and transcendence in order to avoid a theology leaning towards panentheism. Nevertheless, this statement comes at a price: there is no substantial critical discussion of divine intervention in healing, prayer, faith, laying on of hands, claims of the miraculous and so on. This is a seemingly glaring omission for a book that claims to cover spirit and healing in Africa. God is seemingly strictured. A mere Christian sociological use of the term 'God's life' (p. 203) is offered instead - it is never quite defined, but seems to relate to the continuation of life's gradual transformation by the Spirit into union with Christ (p. 232) and concludes at the end of life (p. 222). Some vague comfort is offered by associating the quality of life and the vulnerability of creation through comprehending the mediation of the Spirit of God in this physical domain of reality (p. 255).

Whether this book will ultimately serve to educate pastors and counsellors to sufficiently comfort a person tormented by weaknesses and misfortune is questionable. Its strength is sociological. For Van den Bosch-Heij it seems that comfort lies in a communal realignment of one's view of health and healing, and acceptance of a God who once acted in creation, but has now become limited through theological redefinition. Whether the reader will be convinced by Van den BoschHeij's claims of promoting Reformed theology remains to be seen.

A book that clearly seeks to support a Reformed view of spectacular cessation of the actual personal intervention of God within the faith community settles for a useful sociotheological approach to spirit, healing and health in Africa. 